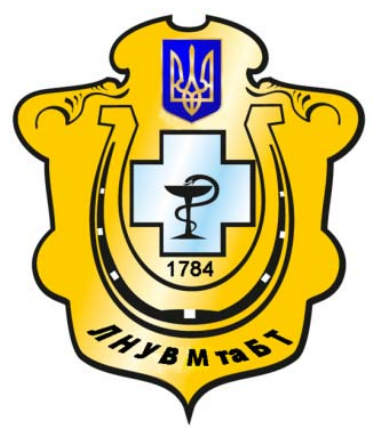

Науковий вісник Львівського національного університету ветеринарної медицини та біотехнологій імені С.3. Гжицького

Scientific Messenger of Lviv National University of Veterinary Medicine and Biotechnologies named after S.Z. Gzhytskyj

doi:10.15421/nvlvet6628

ISSN 2413-5550 print

ISSN 2518-1327 online

$\underline{\text { http://nvlvet.com.ua/ }}$

УДК 591.472:598.235

\title{
Біоморфологічні особливості скелетних елементів плечового суглоба пінгвіна гумбальта
}

\author{
О.О. Мельник, М.В. Мельник, В. Кінда, Д. Кубяк-Новак \\ melnik_oo@nubip.edu.ua,masha.vet2011@yandex.ru, wojciech.kinda@up.wroc.pl,doma8@up.pl \\ Національний університет біоресурсів і природокористування Украӥни, \\ вул. Героїв Оборони, 11, м. Київ, 03041, Україна; \\ Вроиялвський університет біоресурсів і природокористування, \\ C.K. Norwida, 25, 50-375, Врочлав, Польща
}

В статті викладено результат та аналіз остеометричних досліджень скелетних структур плечового суглоба пінгвіна Гумбальта (Spheniscus humboldti). Проведено статичтичну обробку отриманих результатів та визначено відсоткове співвідночення скелетних структур плечового суглоба пінгвіна Гумбальта. Встановлено певні видові особливості та закономірності, щи вказують на специфічні біоморфологічні адаптації до «підводного польоту». Зокрема ключиці зростаючись y «вилочку» не прикріплюється до груднини.Встановлено, щьо ластоподібна форма грудної кінцівки, а також певні особливості будови скелетних структур плечового суглоба пінгвіноподібних, зокрема сплюснута плечова кістка, каудально розширена лопатка, потужні коракоїд та вилочка очевидно спричинені дією підвищених функціональних навантажень, щзо виникли як наслідок пристосування до виконання гребних функиій крилом під час швидкого і глибинного плавання під водою, так як пересування під водою викликає ще більщі фізичні навантаження.

Ключові слоба: біоморфология, пінгвін Гумбальта, плечовий суглоб, птахи, остеометричні дослідження, плечова кістка, лопатка, ключичя, коракоїд, скелет.

\section{Биоморфолгические особенносты скелетных элементов плечевого суглоба пингвина гумбальта}

\author{
А.О. Мельник, М.В. Мельник, В. Кинда, Д. Кубяк-Новак \\ melnik_oo@nubip.edu.ua,masha.vet2011@yandex.ru,wojciech.kinda@up.wroc.pl,doma8@up.pl \\ Национальный университет биоресурсов и природопользования Украины, \\ ул. Героев Обороны, 11, Киев, 03041, Украина; \\ Врочлавский университет биоресурсов и природопользования, \\ C.K. Norwida, 25, 50-375, Врочлав, Польша
}

\begin{abstract}
В статье изложены результат и анализ остеометричних исследований скелетных структур плечевого сустава пингвина Гумбальта (Spheniscus humboldti). Проведено статистическую обработку полученных результатов и определено проиентное соотношение скелетных структур плечевого сустава пингвина Гумбальта. Установлены определенные видовые особенности и закономерности, указывающие на специфические биоморфологические адаптачии к «подводному полетуу. В частности ключиць срастаясь в «вилочку» и не фиксируются к грудине.

Установлено, что ластоподобная форма грудной конечности, а также некоторые особенности строения скелетных структур плечевого сустава пингвиноподобных, в частности сплюснутая плечевая кость, каудально расширеная лопатка, мощные коракоид и вилочкой очевидно вызванные действием повышенных функииональных нагрузок, возникших как следствие приспособления к выполнению гребных функций крылом вовремя быстрого и глубокого плавания под водой, так как передвижение под водой вызывает еще бильшие физические нагрузки.
\end{abstract}

\section{Citation:}

Melnyk, O.O., Melnyk, M.V., Kinda, W., Kubiak-Nowak, D. (2016). Biomorphologikal features of skeletal elements of shoulder joint of humboldt pinguin. Scientific Messenger LNUVMBT named after S.Z. Gzhytskyj, 18, 2(66), 136-139. 
Ключевые слова: биоморфология, пингвин Гумбальта, плечевой сустав, птииы, остеометрические исследования, плечевая кость, лопатка, ключица, коракоид, скелет.

\title{
Biomorphologikal features of skeletal elements of shoulder joint of humboldt pinguin
}

\author{
O.O. Melnyk, M.V. Melnyk, W. Kinda, D. Kubiak-Nowak \\ melnik_oo@nubip.edu.ua,masha.vet2011@yandex.ru,wojciech.kinda@up.wroc.pl,doma8@up.pl \\ National University of life and environmental sciences of Ukraine, \\ Heroyiv Oborony Str., 11, Kyiv, 03041, Ukraine; \\ Wroclaw University of Enviromental and Life Sciences, \\ C. K. Norwida, 25, 50-375 Wroctaw, Poland
}

\begin{abstract}
The article presents the results and analysis of osteometric research of skeletal structures of the shoulder joint of Humboldt penguin (Spheniscus humboldti). Statistical analysis of the obtained results was made and the percentage ratio of the skeletal structures of the shoulder joint of Humboldt penguin was determined. Certain species features and natural laws were established that point out specific biomorphological adaptations to the «underwater flight». In particular clavicles that accrete into a «fork» are not attached to the sternum. This allowed us to understand certain patterns of their development.
\end{abstract}

The shoulder joint of birds is a complex joint that is formed by bones of shoulder girdle and humerus. A coracoid is the most developed bone of the shoulder girdle. It should be noted that coracoid of birds is characterized by a high degree of development, which is caused by the development of muscles of wing that are fixed to it. The proximal end of coracoid forms a so-called acrocoracoidal process, to which a collarbone is fixed. The distal end of coracoid is connected to sternum, thus forming a coraco-sternal joint that is characterized by low motility.

It was found that flipper form of thoracic limb and certain structural features of skeletal structures of the shoulder joint of Sphenisciformes, in particular flattened humerus, caudaly extended scapula, powerful coracoid and furcula are apparently caused by the influence of increased functional loads that have arisen as a result of adaptation to perform rowing functions by wing during rapid and deep swimming under water, because movement under water requires more physical activity.

Penguins (Humboldt penguin) are characterized by greatly elongated and expanded in its caudal part scapula (Annex A-3, Fig. 3.5). Its length relatively to the length of the humerus is $150 \%$, and in the widest part-more than $20 \%$ of the scapula length. It should be noted that in caudal part of scapula is small, not ossified area that is covered with connective tissue membrane. In studied species acromion of scapula is directed upwards. Furcula in penguin is much expanded in its proximal part. Coracoid is like a column and elongated. Its length relatively to the length of the humerus is $111.1 \%$. Underlying of coracoid is relatively narrow. Width of the coracoid base relatively to the lengths is $29.1 \%$. On the lateral edge of coracoid base is a small appendage, directed proximally. In addition, the lateral edges of coracoid in studied bird species has so-called coracoid window. This window is formed as a result of coracoid ligament ossification. The proximal end of coracoid is bended laterally. Humerus in Humboldt penguin has a flattened shape. Its length relatively to the total length of the wing is 33.5\%. Pneumatic fossa is large enough.

Key words: biomorphological, Humboldt pengui, shoulder joint, birds, osteometric research, humerus, scapula, clavicles, coracoid, skelet.

\section{ВстуII}

Порівняльно-анатомічні дослідження органів локомоції тваринних організмів вже не одне століття досліджували багато вчених. Не було винятком і вивчення органів локомоції птахів. Ще у 1899 році видатний вчений свого часу К. Е. Ліндеман (Lindeman, $1899)$ зазначав, що «Порівняльна анатомія ... вивчена в теперішній час дуже недосконало». Не дивлячись на те, що $з$ того часу минуло вже більша ніж сто років, порівняльна анатомія має більше запитань ніж відповідей на них. Одним із далеко не вивчених залишається питання еволюції органів локомоції хребетних, зокрема питання будови скелетних структур плечового суглоба хребетних взагалі та птахів зокрема. До нині не вирішеними залишаються питання походження скелетних структур. В цьому сенсі надзвичайно важливими і актуальними є дослідження скелетних структур плечового суглоба птахів.

Цікавість до вивчення анатомічної будови птахів зростає після знаменитої роботи батька порівняльної анатомії - барона Ж. Кювьє (Cuvier, 1800), що фактично заклала основи порівняльно-анатомічного методу у вивченні тварин.
На початку XIX-го століття виходить низка праць 3 анатомії свійської птиці (Hutchinson, 2002), м'язів галки (Stallcup, 1954), королівського пінгвіна та сови (Earls, 2000), чорної ворони (Mellet, 1985), Столп (Stolpe and Zimmer, 1937) публікує роботу, в якій описує загальні риси будови скелета у зв'язку з характером руху в суглобах. Велику увагу приділяе при цьому суглобовим поверхням кісток і зв'язковому апарату.

Як зазначають дедеякі автори, дещо пізніше робота Ватсона про пінгвінів, перевершила згадану монографію Гадова (Glutz von Blotzheim, 1960), і навіть містила дані з артрології.

\section{Матеріал і методи досліджень}

Матеріал для досліджень було одержано із фондів кафедри анатомії тварин ім. акад. В.Г. Касьяненка Національного університету біоресурсів і природокористування України, Київського зоопарку, кафедри анатомії тварин Вроцлавського природничого університету.

Дослідження проводилися на представниках Ряду Пінгвіноподібн Ordo Sphenisciformes, а саме на пінг- 
віні Гумбальдта Spheniscus humboldti у кількості 5 представників від даного виду. Остеологічні дослідження проводились за допомогою штангенциркуля за розробленою нами схемою (рис. 1).

Досліджені птахіи характеризуються специфічними біоморфологічними адаптаціями, що обумовлені пристосуванням до плавання під водою.

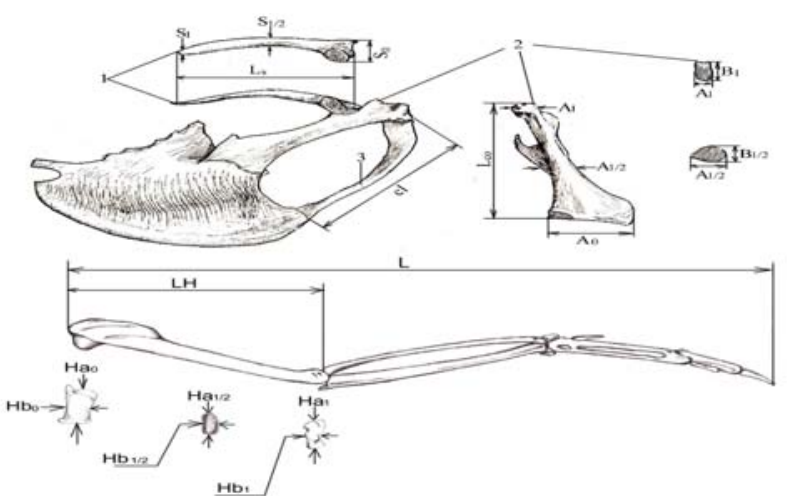

Рис. 1. Схема промірів скелетних структур плечового суглоба птахів

Під час дослідженя скелетних структур плечового суглоба птахів, крім опису будови кісток, що його утворюють, здійснювали їх морфометрію згідно 3 розробленими схемами (рис. 2.), а саме: Lco - довжина коракоїда; $\mathrm{A}_{0}$ - ширина коракоїда на рівні його основи; $\mathrm{A}^{1} \frac{1}{2}$ - ширина коракоїда на рівні $1 \frac{2}{2}$ його довжини; $\mathrm{A}_{1}$ - ширина проксимального кінця коракоїда; В $1 \frac{2}{2}$ - товщина коракоїда на рівні $1 \frac{2}{2}$ його довжини; В1 - товщина проксимального кінця коракоїда; Ls - довжина лопатки; $\mathrm{S}_{0}$ - ширина лопатки на рівні їі основи; $\mathrm{S} 1 / 2$ - ширина лопатки на рівні $1 / 2$ iї довжини; $\mathrm{S}_{1}$ - ширина лопатки на рівні іiі каудального кінця; $\mathrm{cl}$ - довжина ключиці; L - загальна довжина крила (відстань від проксимального кінця плечової кістки до дистального кінця II-го пальця; LH - довжина плечової кістки; $\mathrm{Ha}_{0}$ - сегментальний діаметр проксимального кінця плечової кістки; $\mathrm{Hb}_{0}$ - сагітальний діаметр плечової кістки; $\mathrm{Ha}_{1 / 2}$ - сегментальний діаметр плечової кістки на рівні середини діафіза; $\mathrm{Hb}_{1 / 2}$ - сагітальний діаметр плечової кістки на рівні середини діафіза; $\mathrm{Ha}_{1}$ - сегментальний діаметр дистального кінця плечової кістки; $\mathrm{Hb}_{1}$ - сагітальний діаметр дистального кінця плечової кістки.

Отриманий цифровий матеріал був оброблений статистично за допомогою компютерної програми «БІОМ». 3 метою проведення функціонального аналізу ми визначали співвідношення структур плечового суглоба між собою, що дало змогу зрозуміти певні закономірності їх розвитку.

\section{Результати та їх обговорення}

Надряд плаваючі, ряд пінгвіни об'єднує плаваючих та пірнаючих, однак нелітаючих птахів, що здатні пірнати на значні глибини і плавати під водою зі швидкістю до 40 км/год. Цьому сприяють біоморфологічні адаптації, у першу чергу перетворення крила на еластичний ласт, подібний за формою до плавців акул. Ці ластоподібні крила, завдяки особливій будові скелета, знаходяться у напіврозтягнутому стані і підчас плавання під водою обертаються у плечовому суглобі майже гвинтоподібно. Це, у свою чергу, наклало і певні відбитки на будову скелетних структур плечового суглоба.

Так, для пінгвіноподібних (пінгвін Гумбольдта) характерна значно видовжена i розширена, у своїй каудальній частині, лопатка (рис. 2).

Її довжина відносно довжини плечової кістки становить $150 \%$, а ширина, у найбільш широкій частині більше 20\% від довжини лопатки. Слід зазначити, що у каудальнії частині лопатки є невелика, неосифікована ділянка, що затягнута сполучнотканинною мембраною. У дослідженого виду акроміон лопатки направлений вверх. Вилочка у пінгвінів, значно розширена у своїй проксимальній частині.

Коракоїд стовпоподібний і видовжений. Його довжина відносно довжини плечової кістки становить $111,1 \%$.

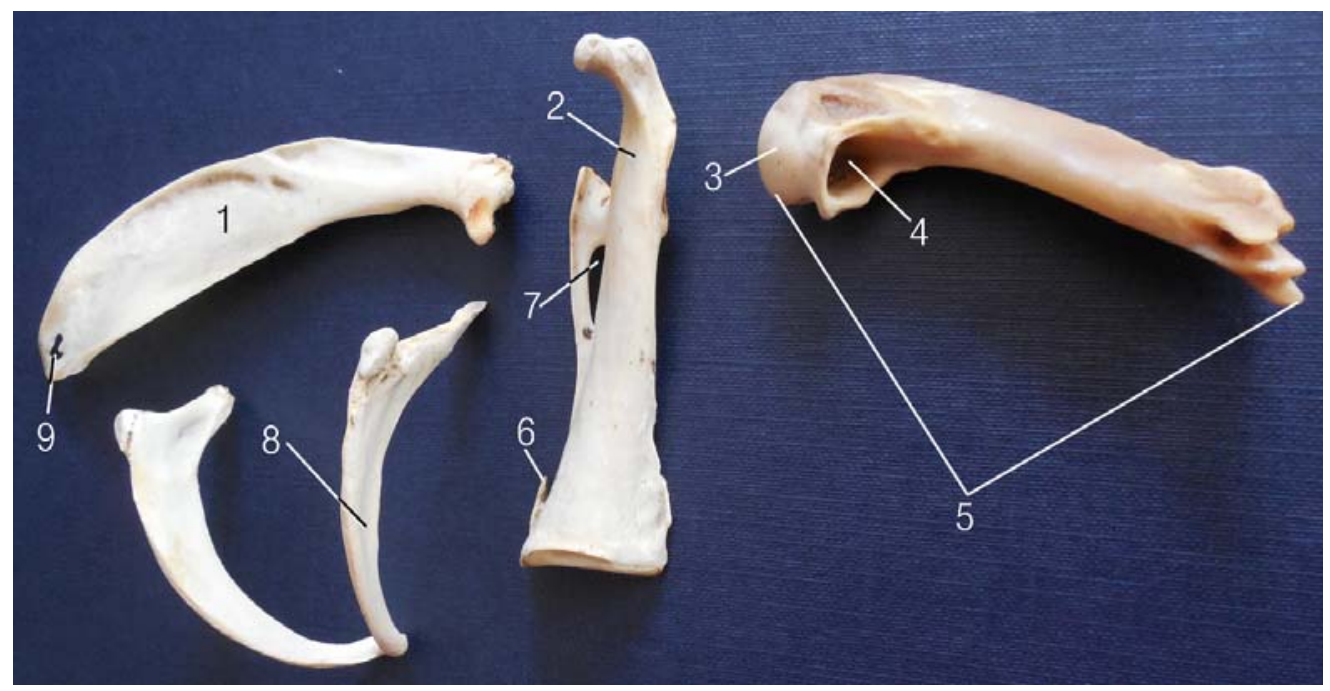

Рис. 2. Скелетні структури плечового суглоба пінгвіна Гумбольдта:

1 - лопатка; 2 - коракоїд; 3 - голівка плечової кістки; 4 - пневматична ямка; 5 - плечова кістка; 6 - латеральний відросток коракоїда; 7 - кракоїдне вікно; 8 - вилочка; 9 - непостійний отвір лопатки. 
У основі коракоїд порівняно вузький. Ширина його основи відносно довжини становить 29,1\%. На латеральному краї основи коракоїда знаходиться невеличкий відросток, направлений проксимально. Крім того, на латеральному краї коракоїда у дослідженого виду птахів знаходиться так зване коракоїдне вікно. Це вікно утворене в наслідок осифікації коракоїдної зв'язки. Проксимальний кінець коракоїда нахилений латерально. Плечова кістка у пінгвіна Гумбольдта має сплюснуту форму. Її довжина відносно загальної довжини крила становить $33,5 \%$. Пневматична ямка досить велика.

Морфометричні показники скелетних структур плечового суглоба досліджених пінгвіноподібних наведено у табл. 1. Співвідношення цих структур наведено у табл. 2 .

Табличя 1

Остеометричні показники скелетних структур плечового суглоба та крила пінгвіна Гумбольта, мм.

\begin{tabular}{|c|c|c|c|c|c|c|c|c|c|c|c|c|c|c|c|c|c|c|c|}
\hline \multirow{2}{*}{ 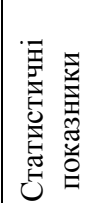 } & \multicolumn{19}{|c|}{ Показники промірів } \\
\hline & $\mathrm{L}$ & LH & $\mathrm{Ha} 0$ & $\mathrm{Hb} 0$ & $\mathrm{Ha} 1 / 2$ & $\begin{array}{l}\mathrm{Hb} \\
1 / 2\end{array}$ & Ha1 & $\mathrm{Hb} 1$ & Ls & S0 & $\mathrm{S} 1 / 2$ & S1 & Lco & A0 & $\mathrm{A} 1 / 2$ & $\mathrm{~B} 1 / 2$ & A1 & B1 & $\mathrm{cl}$ \\
\hline \multirow{5}{*}{$n=5$} & 213,3 & 71,5 & 20,5 & 15,0 & 14,5 & 5,6 & 20,5 & 7,8 & 104,6 & 11,5 & 19,0 & 12,1 & 76,9 & 22,8 & 13,5 & 6,0 & 10,2 & 11,6 & 58,1 \\
\hline & 214,9 & 72,2 & 21,2 & 17,1 & 15,1 & 6,0 & 21,0 & 8,2 & 105,2 & 12,1 & 19,8 & 12,7 & 77,0 & 23,2 & 14,0 & 6,6 & 9,8 & 12,0 & 59,2 \\
\hline & 212,8 & 70,7 & 19,8 & 14,6 & 13,9 & 5,0 & 19,8 & 6,9 & 103,8 & 10,8 & 18,7 & 11,8 & 75,8 & 21,0 & 12,9 & 5,8 & 10,0 & 10,8 & 57,6 \\
\hline & 213,9 & 71,7 & 20,7 & 15,4 & 14,6 & 5,8 & 20,4 & 7,7 & 104,9 & 11,7 & 19,2 & 12,4 & 78,0 & 23,0 & 13,7 & 6,2 & 10,4 & 11,9 & 58,9 \\
\hline & 214,0 & 72,0 & 20,2 & 15,1 & 15,0 & 5,6 & 20,0 & 8,0 & 104,2 & 11,1 & 19,0 & 12,2 & 76,9 & 22,2 & 14,0 & 6,3 & 9,9 & 11,5 & 58,4 \\
\hline $\mathrm{M}$ & 213,7 & 71,6 & 20,4 & 15,4 & 14,6 & 5,6 & 20,3 & 7,7 & 104,5 & 11,4 & 19,1 & 12,2 & 76,9 & 22,4 & 13,6 & 6,1 & 10,0 & 11,5 & 58,4 \\
\hline $\mathrm{M} \pm \mathrm{m}$ & $\pm 0,3$ & $\pm 0,2$ & $\pm 0,2$ & $\pm 0,3$ & $\pm 2,9$ & $\pm 0,1$ & $\pm 0,1$ & $\pm 0,2$ & $\pm 0,2$ & $\pm 0,2$ & $\pm 0,1$ & $\pm 0,1$ & $\pm 0,3$ & $\pm 0,3$ & $\pm 0,1$ & $\pm 0,1$ & $\pm 0,1$ & $\pm 0,1$ & $\pm 0,2$ \\
\hline $\mathrm{Cv}, \%$ & 0,3 & 0,7 & 2,3 & 5,6 & 1,3 & 5,9 & 2,0 & 5,7 & 0,4 & 3,9 & 1,9 & 2,4 & 0,9 & 3,5 & 2,9 & 4,3 & 2,1 & 3,6 & 0,9 \\
\hline
\end{tabular}

Таблиця 2

Співвідношення скелетних структур плечового суглоба та крила, \%

\begin{tabular}{|c|c|c|c|c|c|c|c|c|c|c|c|c|c|}
\hline \multirow{2}{*}{ Вид } & \multicolumn{13}{|c|}{ Показники промірів } \\
\hline & $\begin{array}{l}\text { Lco : } \\
\text { LH }\end{array}$ & $\mathrm{A}_{0}:$ Lco & $\mathrm{B}_{1 / 2}: \mathrm{A}_{1 / 2}$ & $\mathrm{~B}_{1}: \mathrm{A}_{1}$ & Ls : LH & $\mathrm{S}_{0}: \mathrm{L}_{\mathrm{s}}$ & $\mathrm{S}_{1 / 2}: \mathrm{L}_{\mathrm{s}}$ & $\mathrm{S}_{1}: \mathrm{L}_{\mathrm{s}}$ & $\mathrm{cl}: \mathrm{LH}$ & LH : L & $\begin{array}{l}\mathrm{Hb} 0: \\
\mathrm{Ha} 0\end{array}$ & $\begin{array}{c}\mathrm{Hb}_{1 / 2}: \\
\mathrm{Ha}_{1 / 2}\end{array}$ & $\begin{array}{c}\mathrm{Hb} 1 \\
\mathrm{Ha} 1\end{array}$ \\
\hline $\begin{array}{l}\text { Пінгвін } \\
\text { Гумбольдта }\end{array}$ & 111,1 & 29,1 & 44,8 & 115 & 150 & 10,9 & 18,2 & 11,6 & 81,5 & 33,5 & 75,4 & 38,3 & 37,9 \\
\hline
\end{tabular}

\section{Висновки}

1. Крила птахів не виконують опорних функцій на субстрат, однак, у пінгвінів вони долають опір води. Це накладає і певні відбитки на ступінь розвитку та форму скелетних структур крила взагалі, та плечової кістки зокрема. Голівка плечової кістки плаваючих птахів, здебільшого має приплюснуту форму, що, суттєво обмежує обертальні рухи у плечовому суглобі та забезпечує стабілізацію крила під час «підводного польоту».

2. Ластоподібна форма грудної кінцівки, а також певні особливості будови скелетних структур плечового суглоба пінгвіноподібних, зокрема сплюснута плечова кістка, каудально розширена лопатка, потужні коракоїд та вилочка очевидно спричинені дією підвищених функціональних навантажень, що виникли як наслідок пристосування до виконання гребних функцій крилом під час швидкого і глибинного плавання під водою.

Перспективи подальших досліджень. Дослідження особливостей скелетних елементів плечового суглоба птахів на широкому порівняльно-анатомічному матеріалі у біоморфологічному напрямку досліджень. Встановлення відмінностей форми та розміру кісток, що формують плечовий суглоб та закономірності становлення та розвитку плечового суглоба птахів.

\section{Бібліографічні посилання}

Lindeman K.E. (1899). Osnovy sravnitel'noj anatomii pozvonochnyh zhivotnyh. SPb.: Izd-vo A. F. Marksa (in Russian).

Cuvier, G. (1800). Leçons d'anatomie comparée. Paris: Baudouin

Hutchinson, J.R. (2002). The evolution of hindlimb tendons and muscles on the line to crown-group birds. Comp. Biochem. Physiol. A Mol. Integr. Physiol. 133(64), 1051-1086.

Stallcup, W.B. (1954). Myology and serology of the avian family Fringillidae, a taxonomic study. Univ. Kans. Nat. Hist. Mus. Publ. 8(2), 157-211.

Earls, K.D. (2000). Kinematics and mechanics of ground take-off in the starling Sturnus vulgaris and the quail Coturnix coturnix. J. Exp. Biol. 203(4), 725-739.

Mellet, F.D. (1985). The ostrich as meat animalanatomical and muscle characteristics. Msc. Agric. Thes. South Africa : Univ. Stellenbosch.

Stolpe, M., Zimmer, K. (1937). Physikalische Grundlagen des Vogelflugels. J. Ornithol. 85, 147-164.

Glutz von Blotzheim, U. (1960). Zur Morphologie und Ontogenese von Schultergurtel, Sternum, und Becken von Struthio, Rhea und Dromiceius. Ein Beitrag zur Phylogenese der Ratiten. Proc. Int. Ornithol. Congr. $12,240-251$.

Стаття надійшла до редакиії 19.09.2016 